\title{
Concentration of dissolved heavy metal around the Rupat waters industrial activity, Malacca Strait
}

\author{
Koko Ondara ${ }^{1}$, Ulung Jantama Wisha ${ }^{1}$, Ruzana Dhiauddin ${ }^{1}$, and Syahrul Purnawan ${ }^{2 *}$ \\ ${ }^{1}$ Research Institute for Coastal Resources and Vulnerability, Ministry of Marine Affairs and Fisheries, Padang 25245, Indonesia \\ ${ }^{2}$ Department of Marine Sciences, Faculty of Marine and Fisheries, Universitas Syiah Kuala, Banda Aceh, Indonesia
}

\begin{abstract}
The Rupat Strait is a water area located between Rupat Island and Dumai City. This area is growing rapidly which is characterized by increasing coastal residential areas, commercial centers, industries, ports and also increasing marine transportation. This increase in activity can lead to a decrease in the water quality of the Rupat Strait. This study aims to analyze the water quality of heavy metals Cadmium (Cd), Cuprum (Cu), Lead (Pb), Zinc $(\mathrm{Zn})$ and Nickel $(\mathrm{Ni})$ in the waters of the Rupat Strait. Sampling of surface water using sample bottles was carried out at 9 observation stations from the waters of West Rupat to South Rupat, then testing the water samples in the laboratory. The results of the analysis show that the lead and nickel values still meet the threshold values set by the Minister of Environment No.51 of 2014 . A total of $30 \%$ of the sample points for cadmium testing water do not meet the quality standards and have been polluted. Meanwhile, the values of cuprum and zinc have exceeded the specified quality standards and have polluted the waters of the Rupat Strait. There is a need for a mechanism from various aspects to maintain water quality that still meets the threshold and certain efforts are needed to reduce heavy metal pollution, namely cuprum and zinc in the waters of the Rupat Strait and its surroundings.
\end{abstract}

\section{Introduction}

Heavy metals are metal elements that have density exceeds $5 \mathrm{~g} / \mathrm{cm} 3$ which are classified as pollutants and are dangerous because they will accumulate in the water column, sediments, organisms and cannot be degraded naturally [1]. Heavy metals are one of the factors in determining the status of water quality [2]. Heavy metal concentrations that have exceeded the threshold will have an impact on the ecosystem around these waters [3], [4]. Cuprum is one of the heavy metal in the water that is needed by the body in the physiological processes of the organism. However, the excess can interfere with health or cause poisoning [5], [6]. Cadmium (Cd) which is also toxic can cause poisoning, health problems and can kill certain biota, for example, crustacean biota will die on exposure to $\mathrm{Cd}$ with a concentration of $0.005-$ $0.15 \mathrm{ppm}$ [7].

Rupat Strait is a waters located between Dumai City, Sumatra Island and Rupat Island. The strait is a semienclosed water which makes the oceanographic conditions of these waters very dynamic depending on external factors that influence it [8]. The Rupat Strait is used as one of the water transportation routes that are widely used by industries in the coastal areas of Riau Province, especially Dumai City and Bengkalis Regency. The Rupat Strait also has high fishery potential, especially red shrimp (Panaeus monodon) and white shrimp (Pennaeus sp.) to be developed [9]. The high level of human and economic activity in the Rupat Strait has an adverse impact on environmental health, especially the marine environment [10]-[14]. The Rupat Strait area has different levels of environmental sensitivity according to environmental characteristics. The areas of West and South Rupat, Mampu Island and Lubuk Gaung are areas that are very sensitive to oil pollution. The area has relatively good mangrove vegetation and is a catchment area [15]. In addition, the potential for heavy metal oil pollution is also potential in the Rupat Strait because many of these waters have been converted into berths for commercial ships. Therefore, this study aims to determine the suitability of heavy metals, namely Cadmium $(\mathrm{Cd})$, Cuprum $(\mathrm{Cu})$, Lead $(\mathrm{Pb})$, Zinc $(\mathrm{Zn})$ and Nickel $(\mathrm{Ni})$ in the waters of the Rupat Strait.

\section{Material and Method}

Water sampling of the Rupat Strait was carried out at 9 observation stations (Table 1) from the waters of West Rupat to South Rupat (Figure 1). 5 water quality parameters of dissolved metals, namely cadmium (Cd), Cuprum $(\mathrm{Cu})$, Lead $(\mathrm{Pb})$, Zinc ( $\mathrm{Zn})$ and Nickel (Ni). The water quality data analyzed using the quality standards of the Minister of Environment Decree No. 51 of 2004 [16] to see the suitability of the health of marine waters to biota.

Data collection was carried out when the weather conditions were sunny on August 28 to 30, 2020, for the last 3 (three) days there was no rain and the water sample taken was surface water $(<1$ meter depth). The test was

* Corresponding author: syahrulpurnawan@unsyiah.ac.id 
carried out at the Environmental Laboratory of PT. Mutuagung Lestari in Pekanbaru, Riau to obtain water heavy metal values.

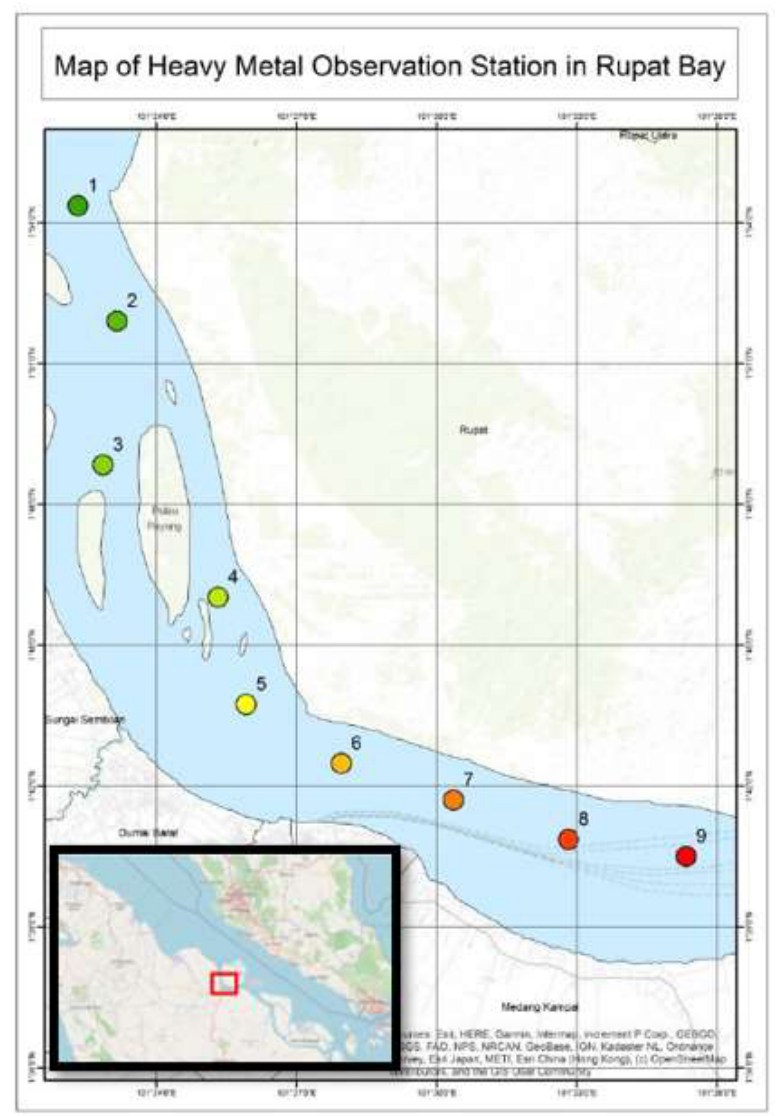

Fig. 1. Observation station map in Rupat Strait.

Table 1. Observation station coordinate.

\begin{tabular}{|c|c|c|}
\hline $\begin{array}{c}\text { Station } \\
\text { Number }\end{array}$ & Longitude & Latitude \\
\hline 1 & 101.372972 & 1.906833 \\
\hline 2 & 101.386750 & 1.865472 \\
\hline 3 & 101.381250 & 1.814917 \\
\hline 4 & 101.422590 & 1.767140 \\
\hline 5 & 101.432690 & 1.729470 \\
\hline 6 & 101.466700 & 1.708330 \\
\hline 7 & 101.506220 & 1.695470 \\
\hline 8 & 101.547570 & 1.681680 \\
\hline 9 & 101.589840 & 1.675250 \\
\hline
\end{tabular}

\section{Results and Discussion}

The cadmium value in the waters of the Rupat Strait ranges from 0.0001 to $0.021 \mathrm{mg} / \mathrm{l}$. The cadmium value at observation stations 1,3 and 4 did not meet the marine water quality standard that had been set at $0.001 \mathrm{mg} / 1$. Cadmium values for observation stations 2, 5, 6, 7, 8 and 9 are below $0.0001 \mathrm{mg} / 1$ and meet the water quality standards for marine biota (Figure 2).

The main sources of $\mathrm{Cd}$ metal contamination are through the earth's layers and human activities [17] such as waste and household waste and fishing activities such as repairing and painting ships [18]. Cd metal can also come from the activity of giving a protective zinc layer to iron and steel to avoid rust [19]. The activity of giving the coating is mostly found in industrial areas located in coastal areas that are prone to rust. The contamination of $\mathrm{Cd}$ sourced from various marine activities is potentially absorbed by marine biota in the form of free ions $\mathrm{Cd} 2+$. This ion is going to be able to compound with chloride ions within $\mathrm{pH} 7.0$, yielding in $51 \%$ $\mathrm{CdCl} 2,39 \% \mathrm{CdCl}+, 6 \% \mathrm{CdCl} 3+$, and $\mathrm{Cd} 2+$ complex about $2.5 \%$ of total concentration.

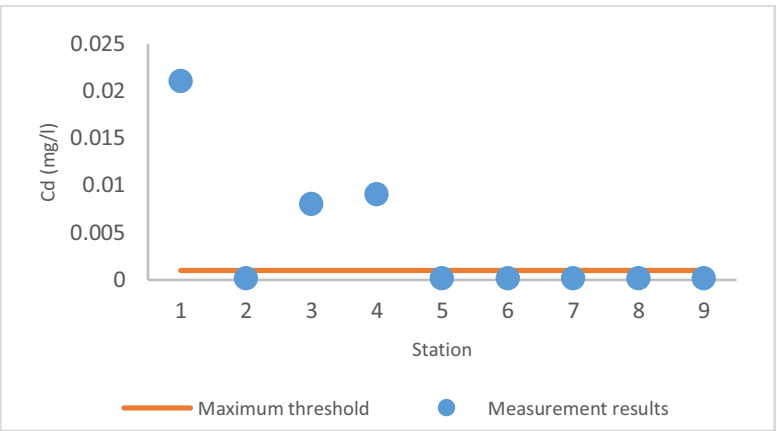

Fig. 1. Cadmium concentration to water quality threshold

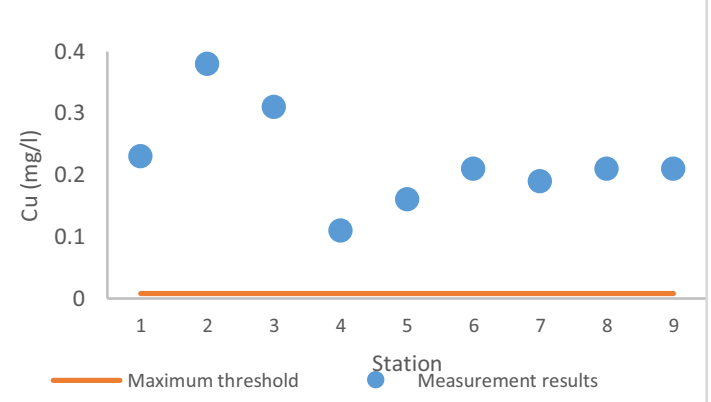

Fig. 2. Cuprum concentration to water quality threshold

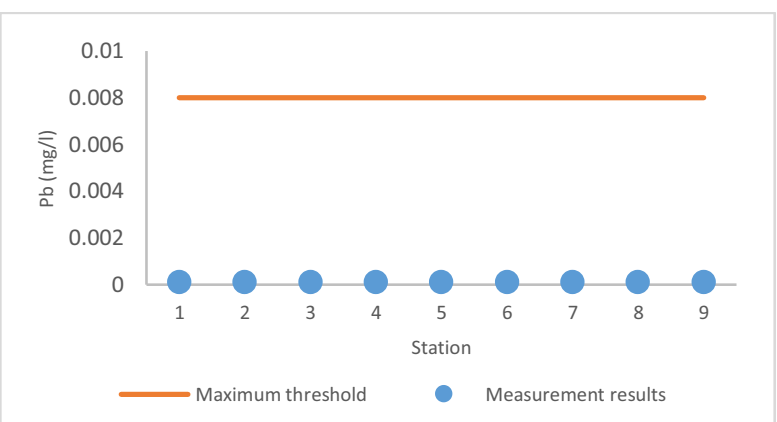

Fig. 3. Lead concentration to water quality threshold

The threshold value for cuprum concentration is $0.008 \mathrm{mg} / \mathrm{l}$. The cuprum value in the Rupat Strait is 0.11 $\mathrm{mg} / 1$ to $0.38 \mathrm{mg} / \mathrm{l}$, so it exceeds the threshold that has been set for all observation points (Figure 3 ). The largest values are at observation stations 2 and 3 which are around the northern part of the estuary. These states showed that the Rupat Strait received sufficiently high $\mathrm{Cu}$-contained pollutant. The Rupat Strait, which the center for marine and port activities, has become the source of heavy metals accumulations. $\mathrm{Cu}$ is contained within the various paint of the ships serving as an antirust paint and antifouling [20]. These materials also contain of $\mathrm{Pb}$ compounds such as $\mathrm{PbCO} 3, \mathrm{~Pb}$ white, and $\mathrm{Pb} 3 \mathrm{O} 4$. 
The lead value in the waters of the Rupat Strait is below $0.0001 \mathrm{mg} / 1$ and is still below the water quality standard for marine biota of $0.008 \mathrm{mg} / \mathrm{l}$ (Figure 4). This result showed that there are no contaminations of lead within the Rupat Strait or perhaps, the device used in the laboratory could not detect the concentration of $\mathrm{Pb}$ which the concentration of lead might be tremendously low. $\mathrm{Pb}$ is kind of heavy metals that relates to the human health, because it could impact on the large number of mankind toxicities, environmental pollution, and harmful toxic properties [21]. This heavy metal is potentially contained within the marine organisms that often consumed by human [22].

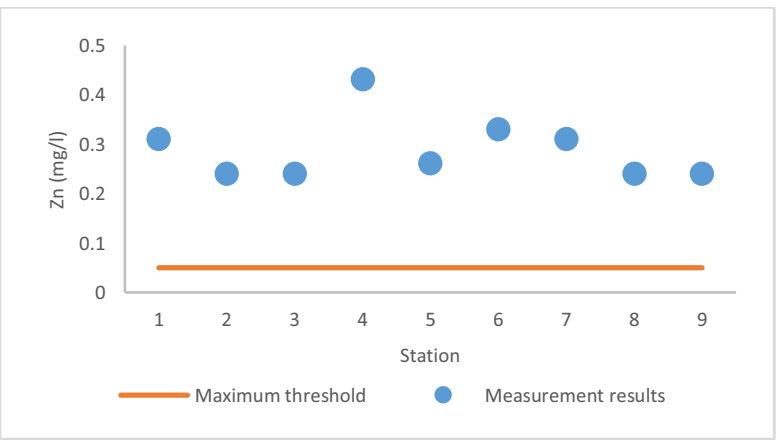

Fig. 4. Zinc concentration to water quality threshold

The zinc concentration in the waters of the Rupat Strait (Figure 5) ranges from 0.24 to $0.43 \mathrm{mg} / \mathrm{l}$. This value exceeds the maximum limit of marine water quality standard of $0.05 \mathrm{mg} / \mathrm{l}$. The high concentration of $\mathrm{Zn}$ could be sourced from the presence of Pier, shipping lane, and ship building activities within the Rupat Strait [23]. This metal can threat the survival ability of local marine biota. Metal distribution in the water environment depends on physiochemical alteration in the water and surface bottom. The precipitation of $\mathrm{Zn}$ and other heavy metals is caused by the alkaline $\mathrm{pH}$ state in the form of insoluble hydroxides, oxides, and carbonates.

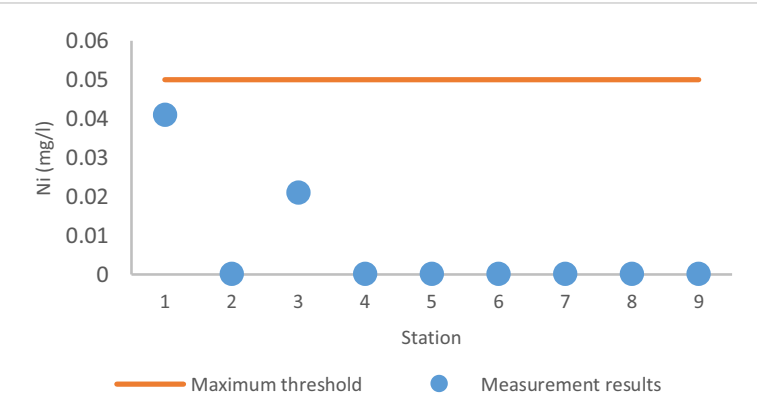

Fig. 5. Nickel concentration to water quality threshold

The nickel concentration in the waters of the Rupat Strait ranges from below 0.0001 to $0.041 \mathrm{mg} / 1$ and is still below the maximum water quality standard set at 0.05 $\mathrm{mg} / \mathrm{l}$. The highest nickel value is at stations 1 and 3 (Figure 6), while for other observation stations it is below $0.0001 \mathrm{mg} / \mathrm{l}$. These states indicate that the nickel metal does not pollute the Rupat Strait. In the waters, nickels have interacted with organic compounds within the aqueous phase and eventually settled in the sediment, resulting a high accumulation of nickel in the sea bottom sediment.

\section{Conclusion}

The values of Lead $(\mathrm{Pb})$ and Nickel (Ni) still meet the threshold values set by the Minister of Environment Decree No. 51 of 2014 . As many as $30 \%$ of the sample locations for Cadmium (Cd) testing waters do not meet the quality standards and have been polluted. Meanwhile, the values of Cuprum $(\mathrm{Cu})$ and Zinc $(\mathrm{Zn})$ have exceeded the specified quality standards and have polluted the waters of the Rupat Strait.

\section{References}

1. N. H. Harun, P. M. Tuah, N. Z. Markom, and M. Y. Yusof, in Int. Conf. Environ. Res. Technol. (2008)

2. N. Y. Gerhanae and Y. Permanawati, J. Geol. Kelaut. 13, 99 (2016)

3. Darmono, Lingkungan Hidup Dan Pencemaran, Hubungan Dengan Toksikologi Senyawa Logam (Universitas Indonesia Press, Jakarta. Indonesia, 2001)

4. A. H. Kusuma, T. Prartono, A. S. Atmadipoera, and T. Arifin, J. Teknol. Perikan. Dan Kelaut. 6, 41 (2016)

5. H. Palar, J. Chem. Inf. Model. 53, 1689 (2004)

6. R.B. Clark, J. Coast. Res. 7, (2012)

7. S. Wulandari, Y. B, G. Santosa, and K. Suwartimah, Indones. J. Mar. Sci. 14, 170 (2012)

8. S. Nedi, B. Pramudya, E. Riani, and Manuwoto, J. Enviromental Sci. 1, 25 (2010)

9. D. Sarianto, S. Asrina Ikhsan, R. bayu Kusuma Haris, and D. Djunaidi, J. Ilmu-Ilmu Perikan. Dan Budid. Perair. 14, (2019)

10. Y. Badrun, J. Enviromental Sci. 1, 17 (2008)

11. G. Geureuha, Natadisastra, Z. Hasan, Sriati, and W. Lili, J. Perikan. Kelaut. 9, 41 (2018)

12. C. E. Larasati, M. Kawaroe, and T. Prartono, Indones. J. Mar. Sci. 20, 223 (2015)

13. K. Ondara, R. Dhiauddin, and U. J. Wisha, J. Kelaut. Nas. 15, (2020)

14. S. Nedi, J. Perikan. Dan Kelaut. 17, 26 (2012)

15. S. Nedi, B. Pramudya.N, E. Riani, and Manuwoto, Model Pengendalian Pencemaran Minyak Di Perairan Selat Rupat Riau, Institut Pertanian Bogor, 2010

16. KLH, Decree of the State Minister of the Environment Number 51 of 2004, Concerning Seawater Quality Standards. (2004)

17. Masriadi, Patang, and Ernawati, J. Pendidik. Teknol. Pertan. 5, 14 (2019)

18. D. Rumahlatu, Ilmu Kelaut. Indones. J. Mar. Sci. 16, 78 (2012) 
19. S. Widowati, A. Sastiono, and R. Jusuf, Efek Toksik Logam (Andi, Yogyakarta, 2009)

20. E. Rochyatun, M. T. Kaisupy, and A. Rozak, Makara Seri Sains 10, 35 (2006)

21. A. Kumar, A. Kumar, M. Cabral-Pinto, A. K. Chaturvedi, A. A. Shabnam, G. Subrahmanyam, R. Mondal, D. K. Gupta, S. K. Malyan, S. S. Kumar, S. A. Khan, and K. K. Yadav, Int. J. Environ. Res. Public Health 17, (2020)

22. T. Purnomo and M. Muchyiddin, Neptunus 14, (2007)

23. Meilanty, H. Wahab, and Y. Hala, Mar. Chim. Acta 6, 12 (2005) 